\section{Critical Review of Sustainability Priorities in the Heritage Sector: Evidence from Latvia's Most Visited Museums}

\section{Elīna Vikmane}

Latvian Academy of Culture

\author{
Anda Laḳe \\ Latvian Academy of Culture
}

\section{EIS 15/2021}

Critical Review of Sustainability Priorities in the Heritage Sector: Evidence from Latvia's Most Visited Museums

Submitted 02/2021

Accepted for publication 06/2021
A vibrant debate about the role and participation of museums in urbanisation, industrialisation, human rights protection, technological progress, climate change and other global challenges has persisted in the field of museums ever since the boom of theoretical museology, which coincided with the development of the sustainable development concept. However, often culture is considered a part of social sustainability pillar, covering manifestations such as equity, participation, social justice etc. (Murphy, 2012; Vallace et al., 2011; Cuthill, 2010) or ignoring cultural aspects altogether (Chiu, 2004). Many voices have called to promote culture as the fourth pillar of sustainable development as a necessary foundation, condition or groundwork through which understandings of social, economic, and environmental sustainability may appear (Soini \& Birkeland, 2014; Hawkes, 2001). Although the potential of cultural heritage institutions such as museums towards sustainable development is outlined in relevant literature, there has been no radical shift in museum practice (Ross, 2004; Simon, 2010; Nomikou, 2015).

The paper aims to propose the first-ever critical review of sustainable development priorities in Latvia's most popular museums with a view to finding out their strategic priorities and using these findings to identify today's specific thematic development lines relevant to the museum sector within the sustainable development framework and to apply this bottom-up principle to propose potential ways to improve the general goal of Latvia's museum accreditation system - that of promoting sustainable museum practices - with specific pointers and thematic building blocks for the broad umbrella concept of sustainable development.

Research objectives include (1) conducting a critical review of relevant literature to identify the role of cultural heritage within the evolution of the sustainable development concept (2) identifying the themes of sustainable development that have been communicated as strategic priorities to stakeholders by the country's nine most visited museums and (3) using research findings to illuminate and pinpoint a specific array of themes pursuant to the general goal of Latvia's museum accreditation system - that of promoting sustainable museum practices - for the system to serve as a more comprehensive and targeted tool for fostering sustainable development in the heritage sector and beyond.

Qualitative content analysis has been chosen to analyse museum development strategies and their collection, research, and communication policies, that is, the museum strategic documents to be submitted by the museums seeking to receive state recognition. The study covers Latvia's nine most popular museums, whose joint annual share of visits amounts to $50 \%$ of the country's total rate (Latvian Academy of Culture, 2018).

The study reveals substantial diversity in how Latvia's most popular museums approach sustainable development goals while also exposing a few significant downsides. According to the findings, museum priorities

\section{Abstract}

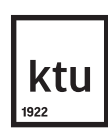

European Integration Studies No. 15 / 2021, pp. 95-109 doi.org/10.5755/j01.eis.1.15.28886 
include (1) heritage preservation, efforts to strengthen national identity, and information and communication technology sustainability in the context of cultural sustainability, (2) financial sustainability as well as tourism-multiplication and image-building in the context of economic sustainability, (3) eco-cultural resilience and improvements in the infrastructure for better energy efficiency as well as a degree of progress towards more sustainable transportation solutions in the context of environmental sustainability and (4) physical, intellectual, socio-economic and emotional accessibility and a focus on boosting social capital in the context of social sustainability. Adjustment of accreditation requirements to meet the sustainable development priorities, at least identified within the study, should, in the long run, raise awareness within the field, enable museums to target their efforts at addressing their downsides and finding possibilities for growth in the context of sustainable development as well as foster sustainable development in the larger field of cultural heritage sites and institutions, which, unlike its kindred sector of museums, exists outside the scope of restrictions associated with accreditation. Such adjustments will help achieve a broader input from the heritage sector towards sustainable development goals.

KEYWORDS: sustainable development, sustainable development goals, cultural sustainability, cultural heritage, museums, museum accreditation

A vibrant debate about the role and participation of museums in urbanisation, industrialisation, human rights protection, technological progress, climate change and other global social challenges has persisted in the field of museums ever since the boom of theoretical museology, which coincided with the trending of sustainable development as a concept. Ever since the UN General Assembly adopted its 2015 resolution, Transforming Our World: The 2030 Agenda for Sustainable Development, setting the objectives for sustainability that emphasised the shared responsibility of every individual and institution, sustainable development goals have become a universal benchmark for the museum sector and its development. At the same time, critical voices have cautioned against underrating the multidimensional role of culture in the categories that define the targets, goals and indicators of sustainable development. These critics have advocated for recognising culture as the fourth pillar of sustainable development or even framing it as a necessary foundation for economic, social and environmental sustainability.

Admittedly, despite this longstanding discussion, sustainability issues have only recently breached the communicative discourse of Latvia's museum sector. Some of the most pertinent examples of this breakthrough include the projects driven by the Latvian Museum Association in 2020, like seminars, webinars and the adding of a sustainability-themed case-study and lived-experience section to Latvia's online museum platform (public-access electronic resource muzeji.lv) in 2020/21, and the national position of ICOM Latvia regarding the need to expand the definition of museums with the concept of sustainable development in 2021 (accepted during the Annual meeting in 2021).

On this note, the paper aims to propose the first-ever critical review of sustainable development priorities in Latvia's most popular museums with a view to finding out their strategic priorities and using these findings to identify today's specific thematic development lines relevant to the museum sector within the sustainable development framework and to apply this bottom-up principle to propose potential ways to improve the general goal of Latvia's museum accreditation system - that of promoting sustainable museum practices - with specific pointers and thematic building blocks for the broad umbrella concept of sustainable development.

Research objectives include (1) conducting a critical review of relevant literature to identify the role of cultural heritage within the evolution of the sustainable development concept (2) identifying the themes of sustainable development that have been communicated as strategic priorities to stakeholders by the country's nine most visited museums and (3) using research findings to illuminate and pinpoint a specific array of themes pursuant to the general goal of Latvia's museum accreditation system - that of promoting sustainable museum practices - for the system to 
serve as a more comprehensive and targeted tool for fostering sustainable development in the heritage sector and beyond.

Qualitative content analysis is used to analyse museum development strategies and their collection, research, and communication policies, that is, accreditation papers from Latvia's nine most popular museums, whose joint annual share of visits amounts to $50 \%$ of the country's total rate (Latvian Academy of Culture, 2018). Details of research design and methodological considerations are outlined further in the paper.

The declaration of the United Nations Conference on the Human Environment (United Nations, 1972) was the first bold effort to reach worldwide agreement on the challenge of sustainable development with its statement - to defend and improve the human environment for present and future generations has become an imperative goal for mankind as previously development and conservation had been regarded as conflicting ideas (Paxton, 1993), with the former directed at exploitation and the latter - at protection. Later Prescot - Allen (1980) defined sustainable development as development that is likely to achieve lasting satisfaction of human needs and improvement of the quality of human life. However, the sustainable development definition as we know it was published years later in the so-called Brundtland report, formally - World Commission on Environment and Development (WCED), as part of the Our Common Future report. This report specified sustainable development as development that meets the needs of the present without compromising the ability of future generations to meet their own needs (WCED, 1987) or so-called mutually beneficial growth (Bisk and Bottuć, 2017).

\section{The three-pillar concept}

The Brundtland report was a turning point, when the old ways of industrial progress, wealth distribution and addressing the emerging ecological crisis had become unfeasible, and the main concern was a global redistribution of resources towards poorer nations to encourage their economic growth in order to enable all human beings to achieve their basic needs as well as fairness in the distribution between generations (Du Pisani, 2006; Soini \& Birkeland, 2014). The report triangulated sustainable development dimensions - economy, environment, or ecology with society (Munasinghe, 1993). Later, they become known as the three sustainable development pillars or the triple bottom line (Elkington, 1997), defined as people, planet and prosperity (adding peace and partnership as additional dimension) in a later policy document, The 2030 Agenda (United Nations, 2015) or similarly adding even more pillars like technological sustainability and political participation that is separated from social sustainability (Fuchs, 2006), or three dimensions of space, plus permanence and persons (Seghezzo, 2009).

Explicit discussions about economic sustainability in isolation from other aspects are relatively sparse. Initially defined as the limitations that a sustainable society must place on economic growth (Brown et al., 1987), it is now an essential part of a broader debate on ecological modernisation, green economy, and bio-economy, which aim to combine ecological and social goals of sustainability through economic means (Soini \& Birkeland, 2014). Thus, historically, the environmental dimension was seen as genetic diversity, resilience, biological productivity (Barbier, 1987), continued productivity and functioning of ecosystems, and protection of genetic resources and the conservation of biological diversity (Brown et al., 1987) or environmental health (Purvis et al., 2019). Now more and more institutions worldwide are involved in the ongoing debate about the most effective ways to make buildings and practices more environmentally sustainable, thinking about metrics such as lowering the carbon footprint and paper consumption, water and energy efficiency, waste reduction and recycling, decreasing air, noise and light pollution, fair trade practices, use of local and reusable materials, purchasing and procurement policies, re-engineering HVAC systems, connecting buildings and landscapes to contribute to environmental health, using innovations and
The role of culture within the sustainable development concept 
educating the public (American Alliance of Museums, 2013; National Audit Office, 2015).

The economic perspective is embodied in people, planet, and prosperity, all three pillars of the latest UN resolution in 2015. Bold statements such as 'end poverty and hunger and ensure that all human beings can enjoy prosperous (..) lives' resonates with the earlier concerns about unequal resource distribution among countries, sustainable consumption and production, sustainable management of natural resources and the idea that 'economic (..) progress occurs in harmony with nature', which, in turn, echoes the approach of Soini and Birkeland. Murzyn-Kupisz (2012) elaboration (which is based on Hutter and Rizzo, 1997; Avrami and Randall, 2000; Navrud and Ready, 2002; Rizzo and Towse, 2002; Howard, 2003; Greffe, 2004; Greffe et al., 2005; McLoughlin et al., 2005; Pike et al., 2007; Bowitz and Ibenholt, 2009; Blakely and Leigh, 2010; Murzyn-Kupisz and Gwosdz, 2010; Murzyn-Kupisz, 2010a) specifies several aspects of sustainable socio-economic development, where cultural heritage institutions can have a part. These include direct impact (direct income of organisations), indirect and induced economic impact (tourism multiplication, real estate market, structural changes in the economy), the image of place (among residents, tourists, entrepreneurs and investors), urban/rural regeneration (institutions as flagships of regeneration strategies and a backdrop to regeneration processes), development of knowledge and creative economy (education, cultural capital and inspiration for new products and services), etc.

With growing awareness of the challenges of fragility, persistent inequality, and racial discrimination, social sustainability has been recognised as central to economic growth and poverty reduction (World Bank 2020). It can be identified by concepts such as social welfare (Passet, 1979), quality of life (Macnaghten \& Jacobs, 1997), social progress (Custance \& Hillier, 1998) and the sociocultural domain, which encompasses equity and participation (Munasinghe, 1993). Besides, social sustainability is increasingly seen as important in achieving environmental aims (Boström, 2012). A UN resolution from 2015 emphasises that human beings can fulfil their potential in dignity and equality, 'enjoy (..) fulfilling lives and social (..) progress in harmony with nature' in peaceful, just and inclusive societies, free from fear and violence, focused in particular on the needs of the poorest and most vulnerable, 'with the participation of (..) all people'. The World Bank describes social sustainability as being about inclusive and resilient societies where citizens have voice and governments respond, about creating opportunities for marginalised groups and individuals, and fighting discrimination, exclusion, and violence (World Bank, 2020).

The concept of sustainable development standing on three pillars is criticised both for being (1) a compromise without theoretical background and (2) too simplistic for the complex world we live in. As a compromise, the concept is not entirely acceptable by either side. It is challenged for being ideologically biased, more anthropocentric than eco-centric and endangered by extreme positions on both ends claiming that genuine sustainability and genuine development would, from a purist point of view, be irreconcilable and overworked (Du Pisani, 2006).

Moreover, studies reveal that there is no single point of origin of this three-pillar conception, but rather a gradual emergence from various critiques (Purvis et al., 2019) of economic growth. All pillars have the same conceptualisation problem with the concept of sustainability. There appears to be no original text from which it derives, seemingly just appearing in the literature and commonly taken at face value (Purvis et al., 2019). The approach has been presented as a common view of sustainable development (Giddings et al., 2002) and criticised as a landfill dump for everyone's environmental and social wishlists (Goodland \& Daly, 1996). A few concerned voices have even warned that sustainable development has reached a conceptual dead-end (Sneddon et al., 2000).

For the purpose of this research, the authors are more interested in the second criticism of the triple bottom line - it being insufficient to explain the complexity of contemporary society and its development. Thus, the authors focus on a subjective translation of this concept into priorities by institutional actors for their development and communication with stakeholders. 


\section{Cultural heritage within the debate of culture as the fourth sustainable development pillar}

It is the role of culture or rather the lack of a prominent role of culture in the sustainable development concept that raises many eyebrows, primarily due to the apparent interdependency between culture and society. Nevertheless, the shortage of a clear-cut conceptualisation is just as applicable to cultural as to any other pillar. Culture is hardly ever discussed in terms of sustainability - we can assume that either sustainability is seen as integral to and inseparable from culture as a whole or concerns regarding the sustainability of heritage or cultural practices are raised within economic, social, and environmental contexts. Ultimately, culture shapes what society means by good or right and how it conceptualises development, as well as determines how people act in the world that they inhabit (Agenda 21 for Culture).

The principles of sustainable development and its goals described in numerous international commitments (Rio Declaration: UN, 1992; In From the Margins: European Council, 1997; Convention for the Safeguarding of the Intangible Heritage: UNESCO, 2001; Convention on the Protection and Promotion of Diversity of Cultural Expressions: UNESCO, 2005; The 2030 Agenda: UN, 2015) can be helpful in the management of cultural resources and organisations with economic and environmental awareness, if we look at them from the perspective of ' communities, as carriers, custodians and direct users of cultural heritage resources' (Keitumetse, 2011). The most problematic part here is the missing link between theory and application (Barbier \& Markandya, 2013; Barbier \& Burgess, 2017). The heritage sector wherein heritage is defined as an expression of the ways of living developed by a community and passed on from generation to generation, including customs, practices, places, objects, artistic expression and values (ICOMOS International Cultural Tourism Charter, 1999) in its everyday work does meet countless sustainable development issues, requiring informed decisions about trade-offs.

There are solid attempts to defend the view that culture and creativity contribute to each of these pillars transversally and that the three pillars contribute to the safeguarding of cultural heritage and the nurturing of creativity (UNESCO, 2017), which reflects the idea of culture as the inseparable spiritual domain of any society. For instance, the International Council of Museums (ICOM), the most influential worldwide organisation in the museum sector, by defining museums as institutions in the service of society and its development, open to the public and engaged in the conservation, research, communication and exhibition of the humanity's tangible and intangible heritage and its environment for the purposes of education, study and enjoyment (ICOM, 2007), encourages museums to dig into the resources available on the SDGs and their implementation, which museums can draw on: 'we don't need to reinvent the wheel or start from scratch. So, what have the SDGs got to do with museums? Everything!' (McGhie, 2020). McGhie (2019) invites museums to contribute to the SDGs by focusing on seven key activities - heritage protection, learning opportunities and research in support of the SDGs, enabling cultural participation for all, supporting sustainable tourism, providing management and operations toward the SDGs, and implementing external collaborations and partnerships towards the SDGs.

Others criticise the approach of culture contributing to the three pillars for the many challenges associated with its practical application. Often, culture is considered a part of social sustainability, covering cultural aspects such as equity, participation, and awareness of sustainability (Murphy, 2012), interpreting it as appropriate behaviour and preservation of sociocultural patterns (Vallace et al., 2011) and talking about social capital, social infrastructure, social justice and equity (Cuthill, 2010). A more critical view states that sustainable development policies often examine the cultural dimension within the social one or ignore it altogether (Chiu, 2004).

As a possible solution, many voices have called to promote culture as the fourth pillar of sustainable development because culture is not only an instrument but a necessary foundation and condition and a perspective through which understandings of social, economic, and environ- 
mental sustainability may appear (Soini \& Birkeland, 2014), emphasising that cultural action is required to lay the groundwork for a sustainable future (Hawkes, 2001). A study of scientific discourse around cultural sustainability, comprising 50 full papers, 34 abstracts (including book abstracts), and two book reviews, identifies seven storylines that function as metonyms that embody various meanings of cultural sustainability (Soini \& Birkeland, 2014) among cultural theorists, showing a few contradictory and overlapping ideas not to be missed when analysing sustainable development in culture: heritage (source of identity, sense of place, passing down values etc); vitality (participation, sharing, accessibility of cultural heritage, creativity, nurturing cohesion etc), economic viability (resources for regional development, strengthening of local industries, place-branding etc); diversity (diversity of cultural values, perceptions, cultural acceptance to achieve social acceptance etc); locality (perceptions and cultural rights of those living on the margins of society: ethnic minorities, indigenous people, marginalised people, etc.); eco-cultural resilience (balance and collaboration between humans and nature in policy development), and eco-cultural civilisation (an ecological shift of values and human behaviours, cultural change as the need to transition to sustainable practices). Additionally, development of information and communication technologies play important role in enabling socio-cultural sustainability (Zacher, 2017) both social and cultural sustainability, for example, helping to preserve culture, facilitating learning new skills within vulnerable population or reducing exclusion (Weber \& Zink, 2014). Many of the storylines emphasise the role of cultural heritage in the building or sustaining of identity, also through other pillars, thus proposing to include culture (and, specifically, cultural heritage and cultural practice) as the fourth pillar of sustainable development in every goal. Some storylines show culture as the very foundation of successful economic, social and environmental practices to reach sustainability. Although cultural heritage institutions such as museums' potential towards sustainable development goals seems to have been convincingly outlined in literature, nevertheless, there has been no radical shift in museography or museum practice (Ross, 2004; Simon, 2010; Nomikou, 2015) or at least two have progressed at a visibly different pace. Museums have failed in ambition and met the stimulus of new social theories with a surprising degree of resistance (Low, 2014). Studies on museum work in Britain suggest that this theoretical framework has failed to change traditional museum practices to a full extent - the current trend seems to expose museums as deficient in the inclusion and representation of all social groups (McCall \& Gray, 2013). So far, potential of museums to promote economic, environmental, and social sustainability in the rapidly changing world, unlike their contribution to cultural sustainability, might not been fully realised and appraised.

Historically, content analysis first emerged as a widely used and popular method with recognised quantitative applications when it was introduced in the communications field (Krippendorf, 2004). Later, researchers from different fields expanded the possibilities of content analysis as a qualitative method to understand or explain complex behaviours by identifying and describing both implicit and explicit themes within the data (Guest et al, 2012; Mayring, 2014; Tight, 2019), although the confusion associated with the overlap between different-named forms of analysis has been a long-standing concern (Tight, 2019). Within the present study, qualitative content analysis was chosen as the most appropriate empirically grounded method. Exploratory in process and predictive or inferential in intent, it is commonly used as a research technique for making replicable and valid inferences from texts to the contexts of their use (Krippendorff, 2013). The analysis rests on the notion that the textual material, although created for another purpose and limited in scope, can help infer broader cultural, social and contextual meanings.

Traditionally, the museum accreditation scheme is a peer-based validation of museum operations and impact based on core standards (American Alliance of Museums), industry standards (Arts Council England) or nationally agreed standards (Museums \& Deaccessioning in Europe), supporting museum 
efforts to plan and develop their services (Arts Council England) and raising museum standards (Accreditation Guidance by Arts Council England, 2019). In Latvia, the national museum accreditation scheme started emerging in 1997 with the adoption of Law on Museums and approval of the national accreditation standard by the Cabinet of Ministers in 1998. The scheme is peer-based and administrated by the Ministry of Culture. The first five museums were accredited in 1999. The goal of the accreditation scheme is to promote sustainable museum practices and effective management of the national museum collections, strengthen the public role of museums (..), and ensure that museums operate with quality and professionalism and remain oriented to public interests and needs (In-house Regulations for Museum Accreditation, Ministry of Culture, 2010). The idea behind accreditation suggests that 'initially, the collection was the priority (..) because accreditation established that the weak point was the preservation of the collection and the state of the depository. Both were beyond any criticism (..)'. 'Now it is research-based communication across museums' admits Head of Museum Department (from 2010 to 2018) Jānis Garjānis in a recent round-table discussion (Creative Museum, 2019).

The present study covers Latvia's nine most popular museums (Table 1) from the total of 110 registered accredited museums as of 2020 (Ministry of Culture), whose joint annual share of visits amounts to $50 \%$ of the country's total rate (Latvian Academy of Culture, 2018) of Culture, with the situation remaining essentially the same in 2019. In total, the authors analysed 651 pages of text, covering the priorities of these museums in terms of their development strategies (aimed at one or two terms) as well as the priorities outlined in their collection, research and communication policies in the sought period of accreditation, as stipulated in the Regulations No. 532 by the Cabinet of Ministers from 2006 that specify the course and process of accreditation and list the documents to be submitted by the museums seeking to enter the procedure. Strategic documents of the Latvian National Museum of Art include the priorities of its branch institution - Art Museum Rīga Bourse.

Qualitative content analysis within the present study involved several tasks: (1) discovering themes (categories) and subthemes (subcategories) based on an existing theoretical frame-

\begin{tabular}{l|c|c|c|c}
\hline \multicolumn{1}{|c|}{ Museum } & Abr. & 2018 & 2019 & Period \\
\hline Latvian National Museum of Art, including & LNMA & 208709 & 179814 & $2016-2025$ \\
\hline Art Museum Rīga Bourse & AMRB & 144224 & 194983 & $2014-2023$ \\
\hline Turaida Museum Reserve & TMR & 273312 & 286045 & $2017-2022$ \\
\hline Rundāle Palace Museum & RPM & 263284 & 275449 & $2015-2020$ \\
\hline Museum of Rīga's History and Navigation & MRHN & 238123 & 226507 & $2020-2025$ \\
\hline Bauska Castle Museum & BCM & 183289 & 182853 & $2016-2020$ \\
\hline Rīga Motor Museum & RMM & 155641 & 157200 & $2015-2024$ \\
\hline Latvian War Museum & LWM & 187800 & 148001 & $2018-2022$ \\
\hline Latvian Ethnographic Open-Air Museum & LEM & 149928 & 131828 & 201 \\
\hline
\end{tabular}

Table 1

Museums featured in the study, their abbreviations, visitor numbers and periodization of strategic documents submitted for accreditation

Source: the authors; data from the Ministry of Culture of the Republic of Latvia; Department of Archives, Libraries and Museums, strategic documents submitted by museums to the Ministry of Culture 
Table 2

Content analysis categorisation matrix (example)

Source: the authors

\begin{tabular}{|c|c|c|c|c|}
\hline $\begin{array}{l}\text { Predetermined } \\
\text { category }\end{array}$ & $\begin{array}{l}\text { Predetermined } \\
\text { subcategory }\end{array}$ & $\begin{array}{l}\text { Theoretical } \\
\text { framework }\end{array}$ & Coding rule & Sample of the priority \\
\hline $\begin{array}{l}\text { Economic } \\
\text { sustainability }\end{array}$ & $\begin{array}{l}\text { Tourism } \\
\text { multiplier }\end{array}$ & $\begin{array}{l}\text { Murzyn-Kupisz } \\
(2012) ; \\
\text { McGhie (2019) }\end{array}$ & $\begin{array}{l}\text { Description of the } \\
\text { priority with words } \\
\text { related to tourism } \\
\text { development }\end{array}$ & $\begin{array}{l}\text { Developing a tourist attraction } \\
\text { programme } \\
\text { Exhibition halls featuring } \\
\text { information in English for } \\
\text { museum guests from abroad }\end{array}$ \\
\hline
\end{tabular}

work, (2) creating a categorisation matrix - winnowing themes to a manageable set of subcategories, manually sorting themes into hierarchies, writing the codebook or coding rules, manually identifying anchor samples (Table 2). The authors proceeded throughout the study with the expectation for other subthemes or subcategories to emerge and worked towards constant discovery and continuous comparison of relevant meanings and nuances (Altheide \& Schneider, 2013). Thereby the analysis allowed eliciting standout themes framed as sustainable development priorities of museums.

The codes in the form of phrases or short sentences are manually lifted straight from the dataset. Interpretations of contextual or latent meanings in the data were made as necessary (Zakaria \& Zakaria, 2016). Inter-rater reliability was established by double-checking the subcategories between both researchers and setting down the rule that at least five priority samples from different museums associated with the same subcategory is considered enough to reveal a solid tendency. This process reflects the summative approach to content analysis that quantifies key words and interprets the context of the themes that are developed (Hsieh \& Shannon, 2005).

In Latvia, the normative framework for museum accreditation is set by Museum Law and subordinate regulations by the Cabinet of Ministers. However, museum sustainability issues only appears in even more subordinate normative acts, notably the In-House Regulations by the Ministry of Culture on Museum Accreditation (2010). Even there, it is mentioned only twice: first, to define the goal of accreditation as promotion of sustainable museum practices and effective management of the national museum collections as well as strengthening the public role of museums, and, secondly, to point out, almost as an add-on towards the end, that accreditation statement should describe the museum's potential to guarantee its sustainability. This situation gives museums freedom of interpretation regarding the concept and, at the same time, rules out the option for museums to conduct a systematic assessment of priorities and success stories within the museum sector and, indeed, to strengthen the weaker areas, all of which would make a vital contribution to sustainable museum practices.

In the present study, the authors analysed accreditation submissions serving also as the strategic documents that set the priorities for museum practice. Quantitative analysis yielded only 30 mentions of the term sustainability across 651 pages in total (including 24 unique mentions). Five museums used it in the general sense ( 6 mentions), three museums - in the context of financial sustainability ( 5 mentions), two museums - to speak about social sustainability (9 mentions), one museum in the context of environmental sustainability (1 mention) and one museum referring to high-level national planning documents (3 mentions). Therefore, qualitative content analysis emerged as a critically necessary method to establish how museum priorities are manifested and thereby illuminate the tendencies in museum contributions towards sustainable development goals within a specific timeframe. 


\section{Cultural sustainability}

" Despite an intense international debate about the role of culture in sustainable development as a catalyst to all sustainable development aspects, a separate pillar, or a foundation for all the other pillars, there is a clear consensus about the unique role of the heritage sector as the custodian of cultural heritage, which is made explicit in sustainable development goals. Latvia's museums are equally clear about their key priority - accumulation, preservation, accounting, maintenance, and ongoing replenishment of cultural heritage to provide authentic testaments about the history, development, and importance of cultural heritage in the context of broader historical and contemporary processes, boost their informative value and guarantee the availability of the said heritage to future generations. In fact, none of the following priorities can be fully realised without fulfilling this one: they become either impossible or devoid of meaning and thus essentially pointless.

"An equally clear value and priority are attributed by museums to the strengthening or maintenance of national identity (LNMA, BCM, LWM), boosting self-worth (LNMA) and national self-awareness (MRHN), inspiring pride in relation to heritage (a collection unlike any other museum in the world RMM), maintenance of "uniquely Latvian wisdom derived from the nation's historical traditions" (latviešu dziveszina) (TMR), cultural praxis through the discovery of heritage, local traditions, and the traditionally appraised aesthetics (BCM).

"Digitalisation is another priority across all museums, with a focus on both cultural and social sustainability through keeping museum items, also artworks with exceptional artistic value (especially the unexhibited), both preserved and available to new target groups or through expanding the range of opportunities for existing audiences. However, the digitalisation of museum collections is far from being finished; another important downside is the unavailability of the digitalised segment of the cultural heritage in high resolution. For all that, the current pandemic has brought technological innovations into centre stage, so it is reasonable to expect significant breakthroughs within the field, addressing various sustainability aspects such as education, research, engagement, accessibility, inclusion and many more, strengthening the means of implementing sustainable practices.

\section{Economic sustainability}

" A financially and economically stable facility is among the essential priorities of Latvia's museums. Financial sustainability, that is, sufficient resources for the maintenance of the museum and, consequently, the physical infrastructure of the collections, appears to be a nearly self-sufficient standard for validating museum sustainability. On the other hand, equalling sustainable operations to survival capacity might be either the lowest sustainability threshold or just a misinterpretation of the complex and broad sustainability concept.

» Another critical priority is increasing the revenue for self-maintenance. In addition to providing existing and new services to the public and strengthening its loyalty, a key priority for all museums in the form of complementary activities is their ability to provide highly professional services - specialist advice, expertise, certification, assessment, etc. Other trending priorities are the reception of visiting exhibitions prepared and financed by other legal entities (LWM, LNMA, MRHN), the deposit of items for permanent exhibition needs (RMM), as well as participation in joint exhibition projects (LNMA, RPM, MRHN). The latter type of activity, among its other benefits, helps reduce operational costs.

" In terms of economic sustainability, all the analysed museums prioritise the tourism multiplication priority and boosting incoming tourism - through introducing new products and pro- 
grammes, training tour guides, using multiple languages in their exhibitions, audio-guides and information materials, and strengthening cooperation with partners from the tourist sector.

Image-building emerges as a significant priority of Latvian museums. However, there is no single tendency in their opinions about where said image-building should be focused - on the image of the country in general (LNMA), the museum itself (BCM, MRHN), or the region or city it is located in (RMM subsidiary, RPM). Given that the study deals only with museums of great national importance and features the country's most popular or most visited institutions, it suggests that a more systematic association of museum accreditation criteria with the national priorities of boosting incoming tourism, whilst leaving museums sufficient freedom to determine how they present the country's overall image and purposefully engage with the national tourism priorities, would provide valuable guidelines for state-funded museums and serve the country in terms of more targeted support to existing efforts to encourage and develop incoming tourism.

" Another priority identified in the museum cohort is cooperation with local businesses in areas such as production of souvenirs and copies of historical artefacts (BCM), boosting local services (car maintenance, care sales - RMM; catering of tourist groups - TMR, cooperation with creative industries - LNMA, RMM or development of applied arts - LEM). At present, the accreditation process does not make it incumbent upon museums to find cooperation opportunities to support local or regional economies.

\section{Environmental sustainability}

" Activities towards environmental sustainability were the most complex to analyse in the present study because environmental sustainability priorities tend to be hidden behind other pillars and because environmental sustainability is generally assessed through highly specific quantitative measures, such as the ecological footprint, energy efficiency indicators, etc., which have not been calculated for Latvia's museums. Lack of quantitative guidelines for museums deny museums the possibility to understand the trade-offs of their choices and the effects of their activities with regards to the environment. However, several trends in museum priorities within the study clearly come to the fore:

Eco-cultural resilience - focusing on the human/community-nature relationship within various contexts and landscapes, is one of the most significant priorities, although it is expressed across the broadest spectrum - from descriptions of target audiences (LEM) to forms of educational activities (LWM) to an almost random single mention that the museum is located in a protected area under the European Nature Directives Natura 2000 (BCM). This suggests that neither the concept of environmental sustainability nor eco-cultural resilience has become self-evident in museum priorities. With that, museums, almost by intuition, seem to perceive that their priorities and roles include: maintaining a safe and accessible natural environment that can be used in a variety of ways (BCM); appreciating the value of an intact rural environment around the museum and preserving species diversity while maintaining the largest garden in the Baltic region (RPM); educating the public about the diversity and uniqueness of local natural heritage (TMR); offering educational programmes that involve physical activities out of doors, organisation of environmental clean-up efforts (LWM) or becoming involved in efforts to create new tourist trails (BCM).

" Museums also prioritise environmental sustainability in terms of improvements to their physical infrastructure. They mention reconstructing the heating system and replacing the windows to save heat (LWM), reconstructing the restoration lighting to save electric energy (RPM) or drawing up a reconstruction project (MRHN) explicitly to improve environmental 
sustainability. This suggests that museums demonstrate a general awareness of sustainability in terms of resource-saving. With that, it is important to point out that LNMA and its structural unit MMRB, as well as RMM, have recently acquired reconstructed or brand-new buildings or collection storage facilities, which might explain there being no mention of this environmental sustainability aspect in their strategic documents.

Development of access to transport infrastructure as a priority for sustainable development is ambivalent because it does not necessarily mean progression towards sustainable development goals. For instance, improving individual parking spaces by rendering them more comfortable or free of charge boosts the rates of car use (RPM, LEM). At the same time, some museums prioritise sustainable improvements to the transport infrastructure, such as introducing cycling lanes (BPM), a tourist trail (BCM) or improving public transport schedules for better access to the museum (RMM). It is worth pointing out that museums do not perceive access to transport through the lens of environmental sustainability. Instead, they associate it with social sustainability, aiming to make museum visits more comfortable and financially accessible.

" Museum initiatives, so far, have not extended to prioritising specific environmental sustainability criteria neither in their work with cooperation partners nor in procurement procedures or other activities such as letting out their property (for instance, LWM lends out some of its lands for agricultural use on a long-term contract basis, but is the agricultural approach questioned for environmental sustainability?). In any case, no evidence was found in strategic museum documents. Clearly, this concern deserves systematic attention on the national level, for instance, by stipulating relevant priorities and criteria for issues such as government procurements, requirements for cooperation partners or energy efficiency, which should automatically apply to the museum sector.

\section{Social sustainability}

" Social sustainability aspects in strategic documents of Latvia's most popular museums yielded the broadest spectrum of priorities. The identified focus on the society-heritage interaction is an exceedingly positive sign regarding the input of the heritage sector towards sustainable development. With that, the analysis also exposed a few critical concerns.

Access is a top priority in museum documentation, and it refers to several aspects. One priority is increased physical accessibility and security. However, at the time of the study, only two museums from the entire cohort were fully accessible to visitors with reduced mobility, with the rest being only partially accessible. In-House Regulations by the Ministry of Culture on Museum Accreditation do invite museums to think about access, but no optimum or even minimum standard is set for accreditation. Paradoxically, or perhaps naturally, state-funded museums are incapable of fulfilling state-decreed accreditation priorities, which is precisely why accreditation requirements do not stipulate specific standards for access.

"Access priorities include opening hours (open daily all year round or at least during the high season - RMM, BCM, MRHN, LEM, LWM) or longer workdays (LNMA) and financial availability, with free admission for specific groups or discount days for the public. With that set as priorities, only LWM offers its permanent exhibition free of charge for all. Other museums grant free admission or discounts to various groups that can verify their special status (with a national or local government-issue ID for senior citizens, persons with disability and schoolchildren, or a school-issue application letter). Besides, the exempt categories of visitors are vastly different across museums. For instance, at present, museums do not grant free access at regular intervals, such as once a month, to all persons, especially excluding socially vulnerable groups as single-parent families, former convicts, the homeless, victims of human 
trafficking or abuse, etc., whose vulnerable status is stipulated in national normative acts but who would find it difficult, if not altogether impossible, to present an official document to confirm exemption from pay.

"All museums prioritise accessibility of knowledge through providing accurate and research-based information with their activities, educational programmes and information materials. The information is presented with an increasing diversity when it comes to language. Museums continue to seek new forms of address tailored to specific target audiences. Additional priorities in this category include fighting stereotypes, boosting public involvement and participation (LNMA) or stressing the importance of the museum being available for all regardless of prior preparation, perception or physical abilities, social status, ethnicity, religious views or geographical location (LEM).

" Fostering emotional accessibility, providing opportunities for recreation (MRHN, LNMA), giving visitors emotionally resonant information (RPM, BCM) or an emotional experience (LWM), some visual pleasure (RMM), the joy of play and celebration (LEM) all come under another museum priority.

" Conscious efforts to build and maintain social capital (LNMA) or social ties, interaction and cooperation with multi-level educational institutions are prioritised by all museums in the cohort. This activity is stipulated in a nationwide financial support programme. In addition, some museums tend to promote more specific community associations (war veterans - LWM; rapier enthusiasts - BCM; motor-sports veterans - RMM, sailors - MRHN, artists - LNMA). In a similar way, museums outside the capital seek to connect with their local populations (RPM, BCM, LEM). It also resonates with the final sustainable development goal number 17 - that of promoting cooperation. At the same time, no expectations are raised throughout accreditation procedures about reinforcing existing cooperation efforts or ongoing involvement of ever-new partners, vulnerable communities, or social groups.

The study demonstrates diverse involvement from the country's most popular museums in sustainable development at the strategic level. At the same time, it identifies windows for improvement on both individual or museum level and the national level.

Museum accreditation priorities in Latvia have developed over time and are, as of now, set out in a low-status in-house information document. Thus, the priorities within the museum accreditation process could be easily adjusted from the normative perspective to gradually invite Latvia's museums towards an ever-greater input in sustainable development by using methodological documents attendant to accreditation rules to explain the complexity of the sustainable development concept revealing itself through this study, encourage museums to set priorities, whilst maintaining museum opportunities to choose their own categories or subcategories, set their own goals and assess their own performance. It would (1) specify and give additional value to the general goal of Latvia's museum accreditation system to promote sustainable museum practices, (2) raise awareness of the importance of sustainable development in the museum sector in general, especially beyond the priorities of heritage preservation and financial sustainability and (3) promote positive competitiveness among museums committed to sustainable development, serving as a catalyst for broader appraisal of sustainable practices, a driving force for innovation and an incentive for constantly growing cooperation with players from other sectors, such as education, social services, healthcare, ICT, environmental protection and many more for mutual benefit and overall sustainable development.

Acknowledgment

This research is funded by the Ministry of Culture, Republic of Latvia, project "Cultural Capital as a Resource for Sustainable Development of Latvia, project No. VPP-KM-LKRVA-2020/1-0003 
American Alliance of Museums. (2018). Accreditation Process and Timeline. Retrieved April 1, 2021, from https://www.aam-us.org/programs/accreditation-excellence-programs/accreditation-process-and-timeline/

Arts Council England. (2019). Accreditation Guidance. Retrieved April 1, 2021, from https://www.artscouncil.org.uk/sites/default/files/downloadfile/Accreditation_Guidance_Mar_2019_0.pdf

Arts Council England. UK Museum Accreditation Scheme. Retrieved April 1, 2021, from https:// www.artscouncil.org.uk/supporting-arts-museums-and-libraries/uk-museum-accreditation-scheme

Altheide, D. L., \& Schneider, C. J. (2013). Qualitative Media Analysis. SAGE Publications, Ltd. https://doi. org/10.4135/9781452270043

Antrim, L. N. (2019). The United Nations Conference on Environment and Development. In A. E. Goodman (Ed.), The Diplomatic Record 19921993 (1st ed., pp.189-210). Routledge. https://doi. org/10.4324/9780429310089-10

Assarroudi, A., Heshmati Nabavi, F., Armat, M. R., Ebadi, A., \& Vaismoradi, M. (2018). Directed qualitative content analysis: The description and elaboration of its underpinning methods and data analysis process. Journal of Research in Nursing, 23(1), 42-55. https:// doi.org/10.1177/1744987117741667

Barbier, E., Markandya, A. (2013). A New Blueprint for a Green Economy (p.216). Routledge https://doi. org/10.4324/9780203097298

Barbier, E. (1987). The Concept of Sustainable Economic Development. Environmental Conservation, 14, 101-110. https://doi.org/10.1017/ S0376892900011449

Barbier, E., Burgess, J. (2017). The Sustainable Development Goals and the systems approach to sustainability. Economics: The Open-Access, Open-Assessment E-Journal, 11. https://doi.org/10.5018/ economics-ejournal.ja.2017-28

Bisk, T., \& Boltuc, P. (2017). Sustainability as Growth In Technology, Society and Sustainability: Selected Concepts, Issues and Cases (pp. 239-250). https://doi. org/10.1007/978-3-319-47164-8_16

Boström, M. (2012). A Missing Pillar? Challenges in theorizing and practicing social sustainability. Sustainability: Science, Practice, and Policy, 8, 3-14. https://doi.org/10.1080/15487733.2012.11908080

Brown, B., Hanson, M., Liverman, D., Merideth, R. (1987). Global Sustainability: Toward Definition. Environmental Management, 11, 713-719. https://doi. org/10.1007/BF01867238
Chiu, R. (2004). Socio-cultural sustainability of housing: A conceptual exploration. Housing, Theory and Society, 21, 65-76. https://doi. org/10.1080/14036090410014999

Council of Europe. (1997). In from the margins: A contribution to the debate on culture and development in Europe. (p.376). Council of Europe Publishing.

Creative Museum (2019). Skats no malas var veicināt attīstību. Diskusijas "Akreditācija - muzeju kvalitātes nodrošināšanas mehānisms?" atšifrējums. II dal,a. Retrieved April 1, 2021, from http:// www.creativemuseum.lv/lv/raksti/dienasgramata/skats-no-malas-var-veicinat-attistibu-diskusijas-akreditacija-muzeju-kvalitates-nodrosinasanas-mehanisms-atsifrejums-ii-dala

Culture 21. (2004). Agenda 21 for culture. Retrieved April 1, 2021, from http://www.agenda21 culture.net/ documents/agenda-21-for-culture

Custance, J., Hillier, H. (2002). Statistical issues in developing indicators of sustainable development. Journal of the Royal Statistical Society: Series A (Statistics in Society), 161, 281-290. https://doi. org/10.1111/1467-985X.00108

Cuthill, M. (2010). Strengthening the "Social" in Sustainable Development: Developing a Conceptual Framework for Social Sustainability in a Rapid Urban Growth Region in Australia. Sustainable Development, 18, 362-373. https://doi.org/10.1002/sd.397

Du Pisani, J. A. (2006). Sustainable development-historical roots of the concept. Environmental Sciences, 3(2), 83-96. https://doi.org/10.1080/15693430600688831

Elkington, J. (1997). Cannibals with forks: The triple bottom line of 21 st century business. (p.424). Capstone Pub. https://doi.org/10.1002/tqem.3310080106

Fuchs, C. (2008). The implications of new information and communication technologies for sustainability. Environment, Development and Sustainability, 10(3), 291-309. https://doi.org/10.1007/s10668-006-9065-0

Giddings, B., Hopwood, B., O'Brien, G. (2002). Environment, economy and society: Fitting them together into sustainable development. Sustainable Development, 10, 187-196. https://doi.org/10.1002/sd.199

Goodland, R., Daly, H. (1996). Environmental Sustainability: Universal and Non-Negotiable. Ecological Applications, 6(4), 1002-1017. https://doi. org/10.2307/2269583

Guest, G., MacQueen, K., Namey, E. (2012). Applied Thematic Analysis. (p.320). SAGE Publications, Inc. https://doi.org/10.4135/9781483384436

Hawkes, J. (2004). The fourth pillar of sustainability: Culture's essential role in public planning. (p.80).
References 
Common Ground Publishing.

Hsieh, H.-F., Shannon, S. E. (2005). Three Approaches to Qualitative Content Analysis. Qualitative Health Research, 15(9), 1277-1288. https://doi. org/10.1177/1049732305276687

ICOM. (2007). Museum Definition. Retrieved April 1, 2021, from https://icom.museum/en/resources/ standards-guidelines/museum-definition/

ICOMOS. (1999). International Cultural Tourism Charter: Managing Tourism at Places of Heritage Significance. Retrieved April 1, 2021, from https://www. icomos.org/charters/tourism_e.pdf

ICOM Latvia. (2021). Biedrības kopsapulce. Retrieved April 1, 2021, from https://www.latvia.icom.museum. Iv/LV/Aktualitates/Biedribas_kopsapulce_032021.pdf

Keitumetse, S. O. (2011). Sustainable development and cultural heritage management in Botswana: Towards sustainable communities. Sustainable Development, 19(1), 49-59. https://doi.org/10.1002/sd.419

Krippendorff, K. (2012). Content Analysis: An Introduction to Its Methodology (Third edition). (p.422). SAGE Publications, Inc.

Kultūras ministrija. (2010). Muzeju Akreditācijas iekšējie noteikumi. Retrieved April 1, 2021, from https://www.km.gov.lv/lv/media/1131/download

Latvijas Muzeju biedrība (2020). 7 vebināri Latvijas muzejiem ar Henriju Makgī. Retrieved April 1, 2021, from https://muzeji.lv/lv/specialistiem/7-vebinari-latvijas-muzejiem-ar-henriju-makgi

Latvijas Muzeju biedrība (2021). Jaunā Latvijas Muzeju biedrības sadal̦a "Ilgtspēja muzejos" veicina izpratni, sarunas un zināšanas par dažādiem ilgtspējīgas attīstības aspektiem. Retrieved April 1, 2021, from https://muzeji.lv/lv/specialistiem/ jauna-latvijas-muzeju-biedribas-sadala-ilgtspeja-muzejos-veicina-izpratni-sarunas-un-zinasanas-par-par-dazadiem-ilgtspejigas-attistibas-aspektiem

Latvijas Kultūras akadēmija. (2018).Latvijas muzeju nozīme dažādām sabiedrības mērḳgrupām: Muzeju un sabiedrības mijiedarbība. Retrieved April 1, 2021, from https://www.km.gov.lv/lv/media/1 1649/download

Low, Theodore 2004 (1942). "What Is a Museum?." In Gail Anderson (ed.). Reinventing the Museum. Historical and Contemporary Perspectives on the Paradigm Shift. (pp. 30-43). Lanham, New York, Toronto \& Oxford: Altamira Press.

Mayring, P. (2014). Qualitative content analysis-Theoretical foundation, basic procedures and software solution.(p.144). Retrieved April 1, 2021, from https://www.researchgate.net/profile/ Philipp-Mayring/publication/266859800_Qualitative_content_analysis_-_theoretical_foundation_basic_procedures_and_software_solution/ links/543e2a540cf2d6934ebd0f7d/Qualitative-content-analysis-theoretical-foundation-basic-procedures-and-software-solution.pdf

McCall, V., \& Gray, C. (2014). Museums and the 'new museology': Theory, practice and organisational change. Museum Management and Curatorship, 29(1), 19-35. https://doi.org/10.1080/09647775.201 3.869852

McGhie, H. (2019). How can museums support the Sustainable Development Goals? By supporting people's human right to cultural participation. Retrieved April 1, 2021, from https://www.linkedin.com/pulse/ how-can-museums-support-sustainable-development-goals-henry-mcghie-1d

MacGhie, H. (2020). The Sustainable Development Goals: Helping Transform our World Through Museums. Retrieved April 1, 2021, from https://icom.museum/en/news/the-sustainable-development-goals-helping-transform-our-world-through-museums/

Munasinghe, M. (1993). Environmental issues and economic decisions in developing countries. World Development, 21, 1729-1748. https://doi. org/10.1016/0305-750X(93)90080-S

Murphy, K. (2012). The social pillar of sustainable development: A literature review and framework for policy analysis. Sustainability: Science, Practice, and Policy, 8, 15-29. https://doi.org/10.1080/15487733.2 012.11908081

Murzyn-Kupisz, M. (2012). Cultural, economic and social sustainability of heritage tourism: Issues and challenges. Economic and Environmental Studies, 113-133.

Museums and Deaccessioning. Accreditation scheme. Retrieved April 1, 2021, from https://www.museumsanddeaccessioning.com/parameter/accreditation-scheme/

National Audit Office. (2015). Environmental and Sustainability metrics. Retrieved April 1, 2021, from https://www.nao.org.uk/wp-content/uploads/2015/10/Environmental-and-Sustainability-metrics-briefing-updated.pdf

Nomikou, E. (2015). Museology without a Prefix: Some Thoughts on the Epistemology and Methodology of an Integrated Approach. ICOFOM Study Series, 43a, 203-215. https://doi.org/10.4000/iss.640

Paxton L. (1993). Enviro Facts 3: Sustainable development. Howick, South Africa: Environmental Education Association of Southern Africa 
Prescott-Allen, R. (1980). How to save the world: Strategy for world conservation. (p.150). London: Kogan Page

Purvis, B., Mao, Y., Robinson, D. (2019). Three pillars of sustainability: In search of conceptual origins. Sustainability Science, 14(3), 681-695. https://doi. org/10.1007/s11625-018-0627-5

Ross, M. (2004). Interpreting the new museology. Museum and Society, 2., 84-103. https://doi. org/10.29311/mas.v2i2.43

Ryan, G. W., \& Bernard, H. R. (2003). Techniques to Identify Themes. Field Methods, 15(1), 85-109. https:// doi.org/10.1177/1525822X02239569

Seghezzo, L. (2009). The five dimensions of sustainability. Environmental Politics, 18(4), 539-556. https:// doi.org/10.1080/09644010903063669

Simon, N. (2010). The Participatory Museum. Museum 2.0. (p.388). Santa Kruz, California.

Sneddon, C., Howarth, R., \& Norgaard, R. (2006). Sustainable Development in a Post-Brundtland World. Ecological Economics, 57, 253-268. https://doi. org/10.1016/j.ecolecon.2005.04.013

Soini, K., Birkeland, I. (2014). Exploring the scientific discourse on cultural sustainability. Geoforum, 51, 213-223. https://doi.org/10.1016/j.geoforum.2013.12.001

Tight, M. (2019). Documentary Research in the Social Sciences. (p.218). SAGE Publications Ltd. https://doi. org/10.4135/9781529716559

United Nations (1987). Report of the World Commission on Environment and Development 1987. Retrieved April 1, 2021, from http://digitallibrary.un.org/ record/139811

United Nations (2015). Transforming our world: The
2030 Agenda for Sustainable Development. Retrieved April 1, 2021, from https://sustainabledevelopment. un.org/content/documents/21252030\%20Agenda $\% 20$ for $\% 20$ Sustainable $\% 20$ Development $\% 20$ web.pdf

UNESCO.(2003). Convention for the Safeguarding of the Intangible Cultural Heritage. Retrieved April 1, 2021, from https://ich.unesco.org/en/convention

UNESCO. (2005). Convention for the Protection and Promotion of the Diversity of Cultural Expressions. Retrieved April 1, 2021, from https://en.unesco.org/ creativity/convention/texts

Vallance, S., Perkins, H., Dixon, J. (2011). What Is Social Sustainability? A Clarification of Concepts. Geoforum, 42, 342-348. https://doi.org/10.1016/j.geoforum.2011.01.002

Weber, H., \& Zink, K. (2014). Boon and Bane of ICT Acceleration for Vulnerable Populations. In The Impact of ICT on Quality of Working Life (pp. 177-190). https:// doi.org/10.1007/978-94-017-8854-0_11

World Bank (2020). Five Things You Need to Know About Social Sustainability and Inclusion. Retrieved April 1, 2021, from https://www.worldbank.org/en/ news/feature/2020/09/02/five-things-about-social-sustainability-and-inclusion

Zacher, L. W. (Ed.). (2017). Technology, Society and Sustainability: Selected Concepts, Issues and Cases. (p.442). Springer International Publishing. https://doi. org/10.1007/978-3-319-47164-8

Zakaria, N., Zakaria, N. (2016). Qualitative content analysis: A paradigm shift from manual coding to computer-assisted coding using ATLAS.ti. SAGE Research Methods Cases, 1-6. http://doi.org/10.4135/9 78144627305015599170

\section{ELINNA VIKMANE}

PhD student, Director of MA Programme "Cultural Heritage Governance and Communication"

Latvian Academy of Culture

\section{Fields of interests}

Museology, sustainable development, cultural heritage, cultural theory.

\section{Address}

Ludzas 24, Riga, Latvia

elina.vikmane@lka.edu.lv

\section{ANDA LAKE}

Professor, Head of LKA Research Centre Latvian Academy of Culture

\section{Fields of interests}

Cultural heritage, cultural theory, creative industries, research methodology.

\section{Address}

Ludzas 24, Riga, Latvia

lake.anda@gmail.com
About the authors 